\title{
XRCC6 wt Allele
}

National Cancer Institute

\section{Source}

National Cancer Institute. XRCC6 wt Allele. NCI Thesaurus. Code C50988.

Human XRCC6 wild-type allele is located within 22q13.2-q13.31 and is approximately 43 $\mathrm{kb}$ in length. This allele, which encodes $\mathrm{X}$-ray repair cross-complementing protein 6 , plays a role in DNA repair, homologous recombination, and non-homologous end joining. The allele also plays a role in tumor suppression. 